\title{
МОЖЛИВОСТІ СПЕЦІАЛЬНИХ ПРАВОВИХ РЕЖИМІВ ЕКОНОМІЧНОЇ ДІЯЛЬНОСТІ ДЛЯ ВІДРОДЖЕННЯ ЕКОНОМІКИ УКРАЇНИ
}

\section{OPPORTUNITIES FOR SPECIAL LEGAL MODES OF ECONOMIC ACTIVITY FOR THE REVIVAL OF THE ECONOMY OF UKRAINE}

В статті досліджено використання механізму СПРЕД для відновлення постраждалих регіонів від війни (Донецька, Луганська області) та анексованого Криму. Продемонстровано, що хибні рішенням уряду про скасування пільгового режиму оподаткування в СПРЕД призводять до катастрофічних наслідків та підривають можливість запровадження в Украӥні потужного механізму прискореного розвитку економіки, який успішно застосовується по всьому світу. Обтрунтовано, що метою держави в сфері розбудови СПРЕД є залучення їх ефективних механізмів для вирімення інвестиційних, інноваційних та сочіальних проблем регіонів. Для ичього потрібно: по-перше, оцінити результати роботи СПРЕД; по-друге, визначити основні тенденції розвитку регіонів (економічні, бюджетні, сочіальні); по-третє, проаналізувати проблеми, щуо гальмують необхідні соціально-економічні зміни та негативно впливають на територіі функиіонування СПРЕД; по-четверте, вдосконалити організаційно-економічний механізм та нормативно-правову базу діяльності СПРЕД, враховуючи попередні підпункти; поn'яте, визначити доиільність та перспективи подальшого розвитку СПРЕД, створених в Україні. Доведено, щзо потрібно визначати список галузей та видів господарської діяльності, на розвиток яких спрямовані спеціальні правові режими економічної діяльності. Визначені пріоритети дозволять: зменшити витрати коштів та часу; не допускати розкрадання приватних та державних коштів; розвивати регіональні иільові програми, залежно від стратегії, тощо. Таким чином, пріоритетні види діяльності повинні відповідати наступним вимогам: корелювати з метою та иілями створення СПРЕД; не суперечити державним та регіональним сочіально-економічним програмам розвитку; бути економічно та фінансово доиільними. Розроблено математичну модель економічного розвитку СПРЕД, яка може бути використана для удосконалення системи управління, контролю та моніторингу СПРЕД, щзо дозволить перевести вплив держави 3 екзогенного чинника, щуо спричиняє ризики, перешкоди й загрози, на ендогенний чинник джерело переваг в діяльності зон, щзо зробить їх дієвими інструментами стійкого інноваційного розвитку, проведено кореляційно-регресійний аналіз залежності ВВП СПРЕД від суми інвестииій.

Ключові слова: спеціальні правові режими економічної діяльності, спеціальні (вільні) економічні зони, технологічні парки, території пріоритетного розвитку, державна стратегія. 
The article explores the use of the mechanism for the reconstruction of the affected regions from the war (Donetsk, Luhansk region) and the annexed Crimea. It is demonstrated that the false decisions of the government to abolish the preferential tax regime in the SPEDA lead to catastrophic consequences and undermine the possibility of introducing a powerful economic accelerated economic development mechanism in Ukraine that has been successfully applied throughout the world. It is substantiated that the state's aim in the sphere of developing SPERED is to attract their effective mechanisms for addressing investment, innovation and social problems of the regions. To do this, it is necessary: to evaluate the results of the work of the SPED; to identify the main trends in the development of regions (economic, budgetary, social); to analyze problems that impede the necessary socio-economic changes and adversely affect the functioning of the SPEDD; to improve the organizational and economic mechanism and legal basis of the SPEDD, taking into account the previous sub-items; to determine the feasibility and prospects for the further development of SPEDED, created in Ukraine. It is proved that it is necessary to determine the list of industries and types of economic activity, the development of which are directed by special legal regimes of economic activity. The identified priorities will allow: to reduce the cost of time and money; prevent theft of private and public funds; to develop regional target programs, depending on the strategy, etc. Therefore, priority activities should meet the following requirements: to correlate with the purpose and purpose of the creation of the SPEDD; not to contradict the state and regional socio-economic development programs; be economically and financially feasible. The mathematical model of economic development of SPERED, which can be used to improve the system of control, monitoring and monitoring of SPED, is developed, which will allow transferring the state's influence from the exogenous factor causing risks, obstacles and threats to the endogenous factor - a source of advantages in the activity of the zones that will make their effective tools for sustainable innovation development, a correlationregression analysis of the dependence of GDP on the amount of investment.

Keywords: special legal regimes of economic activity, special (free) economic zones, technological parks, territories of priority development, state strategy.

Вступ. Зараз все частіше обговорюють питання про механізми відновлення постраждалих регіонів і взагалі виведення економіки 3 кризи. Зокрема, про використання для цього спеціальних правових режимів економічної діяльності . I можна почути навіть твердження, що цей механізм не виправдав себе в умовах України. В цьому зв'язку, принципово важливо зрозуміти, чому ж він себе не виправдав?

Фундаментальні основи розвитку спеціальних правових режимів економічної діяльності у національній економіці України закладено в наукових працях таких дослідників, як О. Власюк, I. Волохова, В. Геєць, О. Сгорова, І. Іванович, І. Мамонтова, А. Слюсар, Ю. Уманців, Ю. Швед та ін. Незважаючи на значний рівень наукової розробленості досліджуваної проблематики, поза увагою вчених залишається ціла низка актуальних теоретичних та прикладних питань щодо розвитку СПРЕД у національній економіці України. Зокрема, це стосується дослідження їх важливості для відродження економіки постраждалих регіонів України від проведення АТО. 
Постановка завдання. Продемонструвати, що завдяки використанню механізму СПРЕД можна відродити постраждалі регіони та економіку України.

Методологія. Ряд загальних наукових i спеціальних методів дослідження, зокрема, методи аналізу і синтезу, наукової дедукції і індукції, класифікаційно-аналітичних методів, логічних узагальнень, були використані для досягнення мети роботи.

Результати досліджень. Впродовж 15 років в Україні застосовувався такий інструмент стимулювання інвестицій на визначених локальних територіях як спеціальні правові режими економічної діяльності (СПРЕД). Відповідно до світової практики, відчутний ефект в масштабах країни настає через 10 років після початку їх застосування. В Україні ефективність СПРЕД стала очевидною вже в перше десятиріччя їх функціонування. Проте в наступному періоді відбулося стрімке падіння всіх їх соціально-економічних показників. Основною причиною такої динаміки стало хибне рішення про скасування пільгового оподаткування СПРЕД, це обгрунтовувалось твердженням, що такий захід дасть можливість істотно збільшити надходження до бюджету. Проте, аналізуючи динаміку податкових надходжень до державного бюджету України за період до відміни пільг та після цього можна побачити, що замість зростання надходжень до зведеного бюджету з податку на прибуток підприємств після 2005 року не тільки не підвищились, вони навпаки зменшились, потім після деякого зростання у 2006 - 2008 роках (що важко пов'язати із відміною пільг) знову почали падати і врешті стали фактично навіть меншими, ніж до відміни пільг [1, с. 33].

Відміна державної підтримки після 2005 року практично по всім показникам i в технологічних парках демонструє катастрофічне зниження ефективності (рисунки 1 - 2.).

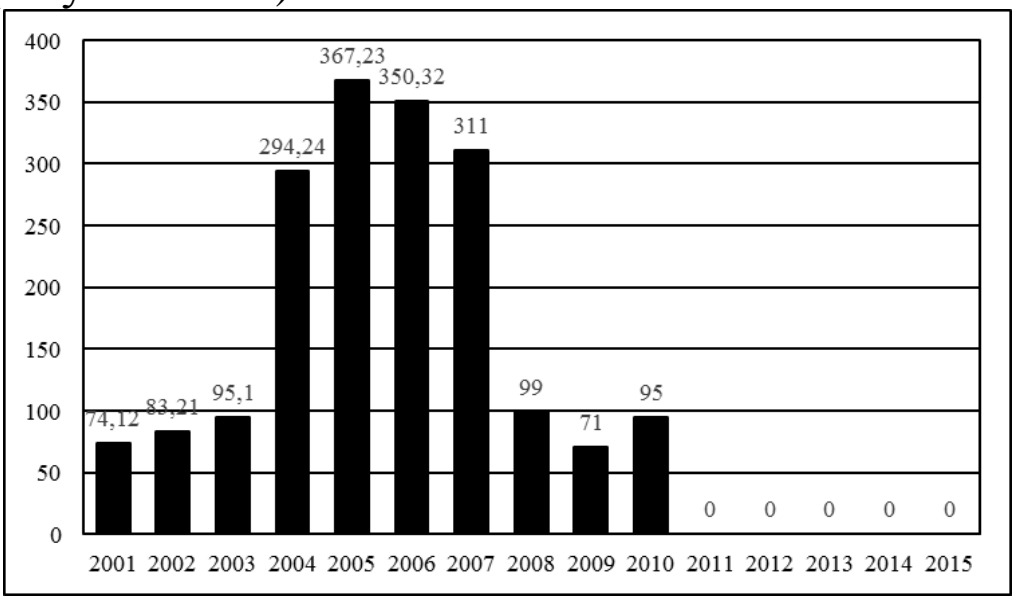

Рисунок 1 - Експорт інноваційної продукції технологічними парками України, 2001-2015, млн грн [2, с. 199; 3]

Як бачимо, відміна пільг для більшості технопарків призвела до того, що період інтенсивного нарощування економічної ефективності (а разом з тим 
і платежів до державного бюджету та державних цільових фондів) після 2006 року змінився на період падіння ефективності i, всупереч сподіванням ініціаторів такого рішення, - зменшення відрахувань державі.

У світовій практиці, окрім Росії та України, СПРЕД рідко створювалися для розвитку депресивних регіонів, адже в такому випадку необхідні значні витрати держави на створення інфраструктури, тому що інвестори не бажають вкладати кошти в інфраструктуру, а воліють використовувати вже налагоджені мережі.

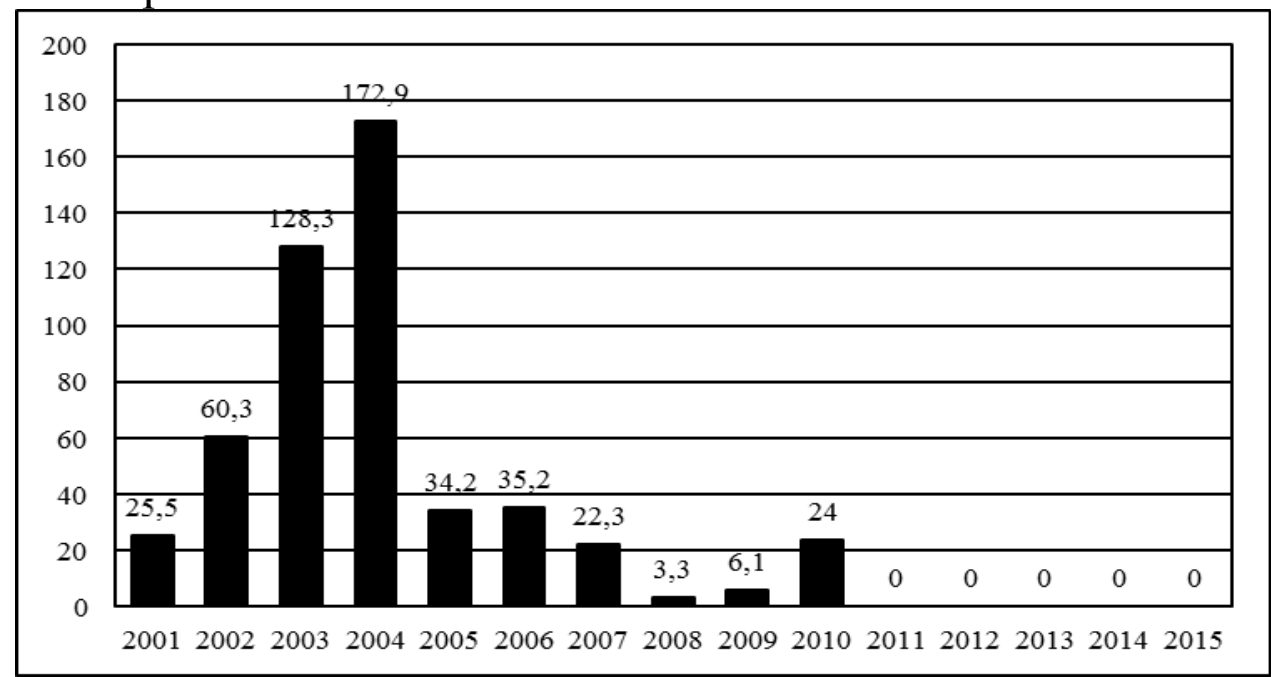

Рисунок 2 - Обсяги державної підтримки технопарків України, 2001-2015 рр., млн грн [2, с. 199; 3]

Чи можливо використати СПРЕД для покращення ситуації? Відповідь, звичайно, ТАК. Світовий досвід підтверджує, що це ефектний механізм стимулювання прискореного економічного розвитку. Особливо актуальним застосування цього механізму може стати для відновлення економіки регіонів, які постраждали від війни Сході України.

На відміну від Китаю, українське законодавство не обумовлювало створення С(В)Е3 та інших СПРЕД і надання пільг за впровадження новітніх технологій, вихід на закордонні ринки високотехнологічної продукції.

У дискусії щодо СПРЕД втрачено головний аспект - зв'язок 3 інвестиційно-інноваційною компонентою економічного розвитку. Якби перед ініціаторами вітчизняних СПРЕД відразу ставилося завдання залучення технологічних компаній та збільшення експорту продукції на ринки промислових країн, то наслідки були б набагато переконливішими.

Досліджено, що для побудови математичної моделі необхідна наявність наступних передумов:

- модель повинна враховувати кількісні відносини між діючим виробництвом на території СПРЕД та його розвитком; 
- чисту валову продукцію виробництва необхідно зробити цільовою функцією, а коефіцієнт реально здійсненного приросту чистої валової продукції виробництва внести в план в якості норми цільової функції.

Ці дві компоненти утворюють кінцевий результат моделі;

- такі змінні як: валова продукція виробництва, загальний обсяг залученого іноземного капіталу, структурне співвідношення капіталу i продуктивності, загальне забезпечення інфраструктури, вимоги до вкладень в земельне освоєння, фінансові кошти, якими володіє СПРЕД, та ін. представляють собою основний зміст плану і є допоміжними показниками, а також інструментальними змінними, що підтримують цільову функцію;

- за своєю формою модель являє собою групу однорідних рівнянь.

Спираючись на багаторазову еволюцію внутрішньо-системних змінних, наближаючись до цільового значення результату обчислення, отримуємо коефіцієнт економічного приросту і цільову функцію (рис. 3).

$\mathrm{y}$ разі якщо цільова функція $є$ незадовільною, можна вдатися до перегляду моделі, збільшити число змінних і рівнянь з тим, щоб задовольнити потребу у врегулюванні системи, а також з метою здійснення контролю та керівництва щодо реальних дій в ході проміжних розрахунках моделі (1).

Нові технології, завезені з-за кордону, якими б передовими вони не були, відносяться до розряду відносно високих, абсолютно високі технології до нас не потрапляють [5].

1.Технології на підприємствах 3 іноземним капіталом $€$ відносно закритими, короткі виробничі ланцюги обмежують їх вихід за межі підприємства. Велика частина підприємств 3 іноземним капіталом після приходу в СПРЕД з точки зору науково-технічних факторів є «десантниками». Ні результати їх експериментальних досліджень, ні проектування продукції, ні навіть які-небудь складні виробничі технології майже ніяк не пов'язані 3 країною, де розташована СПРЕД. У більшості випадків співпраця та операції здійснюються на найнижчому рівні.

$$
\left\{\begin{array}{l}
Y_{t}=Y_{0}(1+r)^{t}, \\
\overrightarrow{X_{t}}=(I-A)^{-1}, \vec{\alpha} Y_{t} \\
\vec{\beta} K_{t}=C^{-1} N\left(\overrightarrow{X_{1}}-\overrightarrow{X_{0}}\right) \\
\overrightarrow{B_{t}}=W \overrightarrow{X_{t}} \\
\rho \vec{\delta}\left(\overrightarrow{B_{t}}-\overrightarrow{B_{0}}\right)=\theta \mu \sum_{j=1}^{t} F_{t} \\
F_{t}=\varepsilon Y_{t}
\end{array}\right.
$$

Економічні значення параметрів, векторів і матриць, які входять в модель: $Y_{t}$ - загальний обсяг ВВП за рік $\mathrm{t}$ прогнозованого періоду, $\mathrm{r}$ - коефіцієнт середньорічного приросту ВВП за прогнозований період, $\vec{X}_{-}$вектор валової промислової продукції $(n \times 1)$ року $\mathrm{t}$ прогнозованого періоду, $\mathrm{n}$ визначається 
числом галузей промисловості, А - діагональна матриця $(n \times n)$ коефіцієнта валового промислового продукту поза ВВП (або коефіцієнт проміжних вкладень), $\vec{a}-$ вектор $(n \times 1)$ частки вкладу у ВВП різних галузей промисловості, $K_{t}$ - загальний обсяг іноземного капіталу, залученого за рік $\mathrm{t}$ прогнозованого періоду, $\vec{\beta}-$ вектор $(n \times 1)$ коефіцієнта залучення капіталу по галузях промисловості, C - діагональна матриця $(n \times n)$ співвідношення капіталу і продуктивності по галузях промисловості, $\mathrm{N}$ - діагональна матриця $(n \times n)$ коефіцієнта вкладу нового капіталу в нову продукцію по галузях промисловості, $\overrightarrow{B_{t}}-$ вектор $(m \times 1)$ забезпечення різного роду інфраструктури за рік $\mathrm{t}$ прогнозованого періоду, $\mathrm{W}-$ матриця $(m \times n)$ коефіцієнта витрачання окремих галузей промисловості стосовно різного роду інфраструктури, $\rho_{-}$ ступінь залежності нових інвестицій в інфраструктуру від бюджету, ${ }^{\vec{\delta}}-$ вектор $(1 \times m)$ коефіцієнта інвестицій, необхідних для питомого забезпечення різного роду інфраструктури, $F_{t}$ - валовий дохід за рік $\mathrm{t}$ прогнозованого періоду, ${ }^{\theta}$ частка витрат на капітальне будівництво в підсумковій сумі валового доходу, $\mu$ - середній відсоток підсумкової суми валового доходу, ${ }^{\varepsilon}-$ частка валового доходу у ВВП.

2. Протягом п'яти років початкового етапу існування СПРЕД через брак кадрів, високу собівартість, а також економічне середовище, орієнтоване на великі підприємства, сповільнилося переміщення сюди малих науковотехнічних підприємств.

3. Великі державні підприємства в зонах розвитку не були безпосередньо одержувачами інвестицій в науку, техніку i технічні перетворення, вони в основному обмежилися підготовкою земельних ділянок, будівництвом базової інфраструктури та нерухомості.

Оскільки описана модель, метою побудови якої $\epsilon$ проведення кількісного аналізу економічної системи СПРЕД, являє собою лише певний хід думок i набір методів, вона $\epsilon$ узагальненням закономірностей економічного розвитку СПРЕД протягом тривалого періоду і 


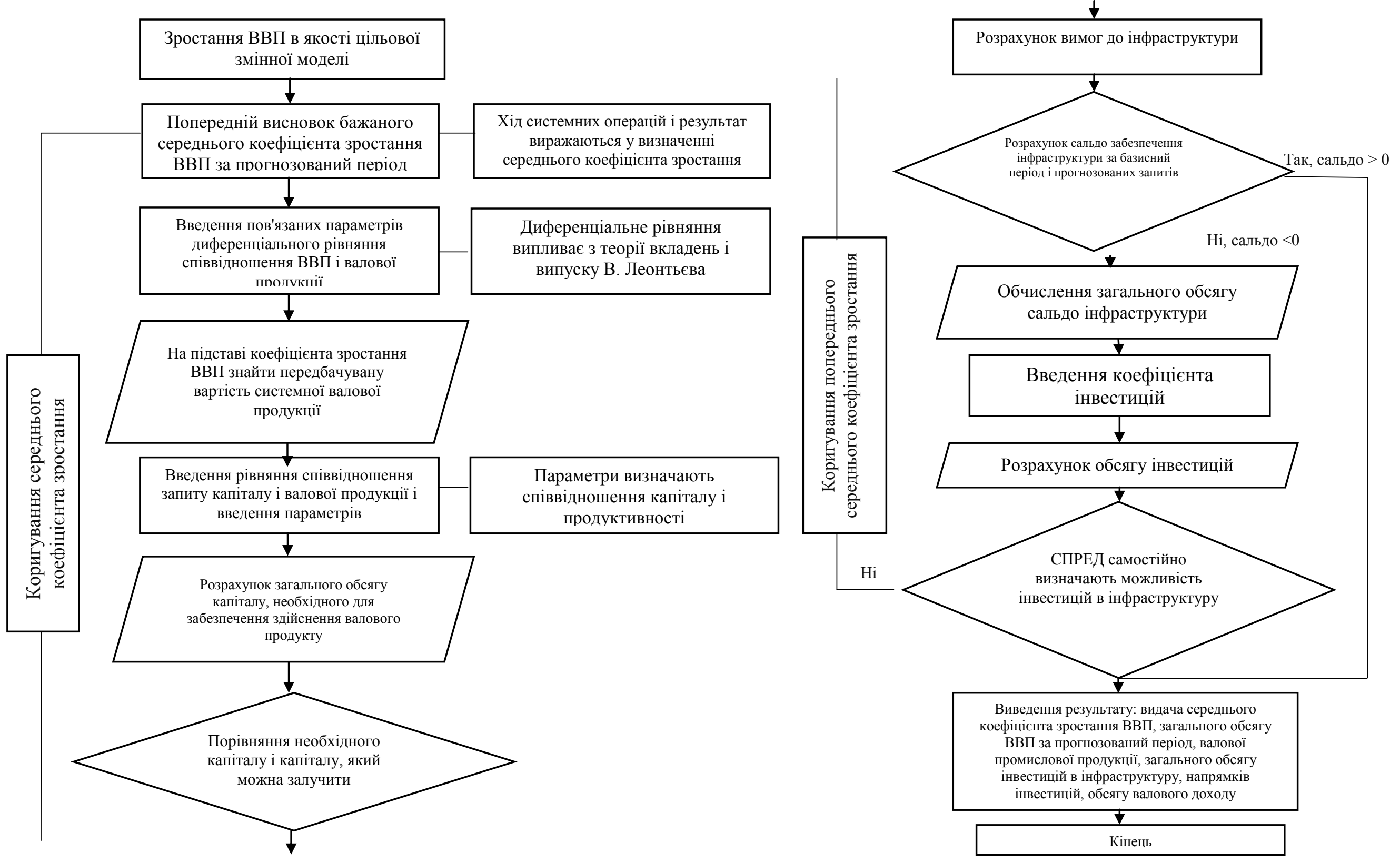

Рисунок 3 - Економіко-математична модель удосконалення системи управління, контролю та моніторингу СПРЕД [авторська розробка] 
не можливо вирішити проблему збору цифрових даних, ми спробували виявити чи є залежність між ВВП СПРЕД, та сумою інвестицій, провели кореляційно-регресійний аналіз (рис.4, рис.5).

Валовий продукт виробляється за рахунок залучених інвестицій, залежність 93 \%, тобто ВВП усього регіону зменшився на $83 \%$ після закриття СПРЕД, частина населення стали безробітними, держава починає видавати дотації населенню, зменшуються надходження до бюджету, регіон стає депресивним.

Якщо говорити про зв'язок між показниками, то з однієї сторони чим він вищий, тим краще для нас, а 3 іншої сторони після закриття зон зменшились надходження в бюджет.

Отримані економіко-математичні моделі можуть бути використані для удосконалення системи управління, контролю та моніторингу СПРЕД, що дозволить перевести вплив держави з екзогенного чинника, що спричиняє ризики, перешкоди й загрози, на ендогенний чинник - джерело переваг в діяльності СПРЕД, що зробить їх дієвими інструментами стійкого інноваційного розвитку [6].

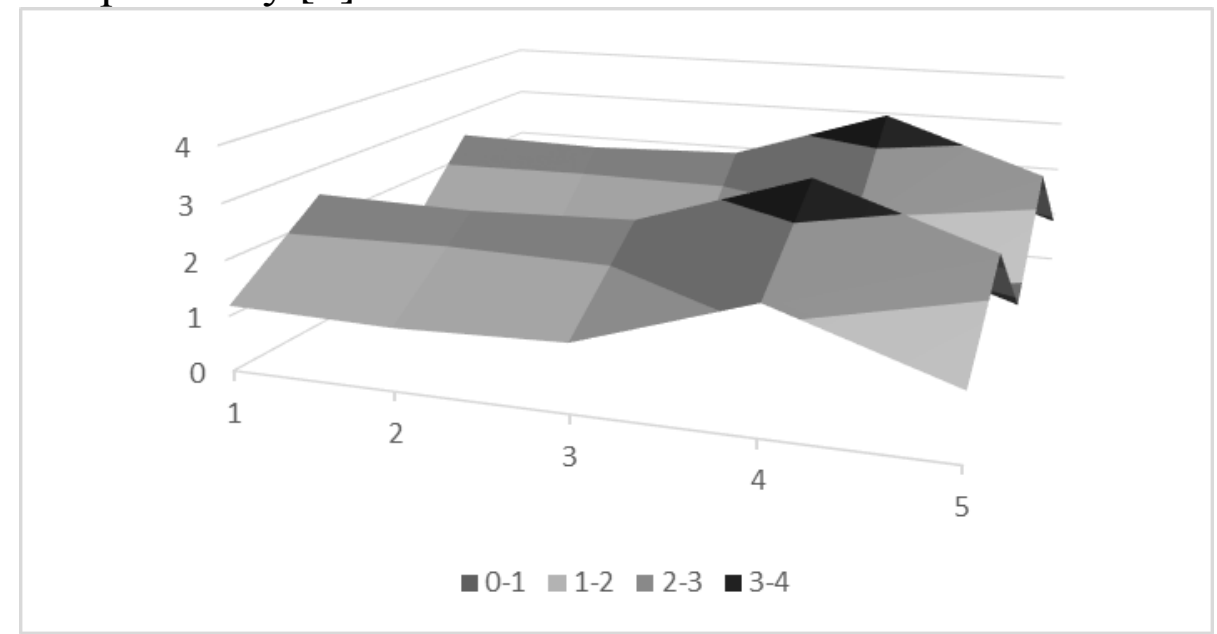

Рисунок 4 - Залучено інвестицій на 1га території / до ВВП з 1га [побудовано автором]

Політика пільг, якою користувалися в СПРЕД підприємства з іноземним капіталом, є різновидом концесії, спрямованої на отримання реальної вигоди. Співпраця університетів і науково-дослідних установ високого рівня із зонами буде покращувати їх науково-дослідні умови, надасть фінансову підтримку, тобто допоможе їм вести спеціальні дослідження і отримувати реальний економічний дохід. Що ж стосується українських і зарубіжних підприємств, які впроваджують нові технології, то вони сподіваються розділити з кимось ризики, отримати початковий капітал. 


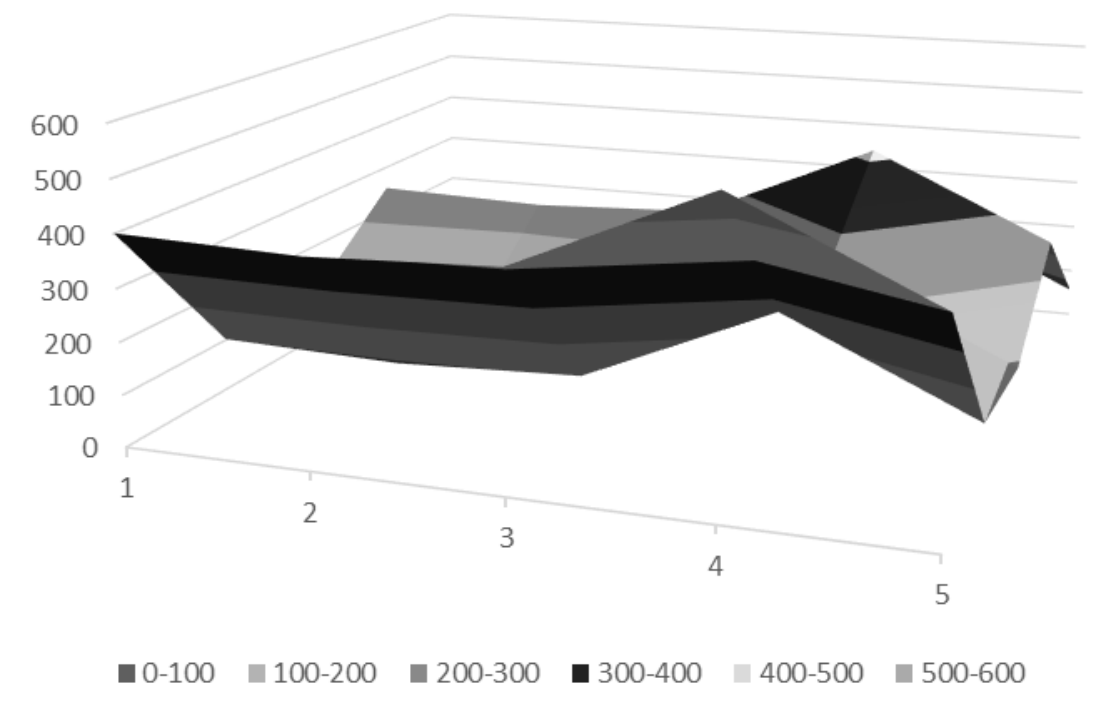

Рисунок 5 - Залучено інвестицій/ виробленого ВВП [побудовано автором]

Висновки. Отже, із самого початку слід будувати роботу в СПРЕД, орієнтуючись на освоєння технологій і ретельно відбираючи іноземні проекти. Необхідно зосередити сили на залученні тих проектів, які б використовували нові технології, випускали нову продукцію, розвивали нові галузі і стали прикладом для українських підприємств тієї ж сфери у справі вдосконалення техніки і підвищення якості продукції. При цьому їх продукція повинна заміщати імпорт або являти собою комплектуючі для внутрішнього виробництва, а іiї постачання за кордон мають стати потужним джерелом валютних надходжень.

Механізм це, як підтверджує світовий досвід, досить ефективний. Його можна і треба використати. Але якщо до нього вдаватися, то треба врахувати наш власний сумний досвід і бути послідовними в його реалізації. Основні уроки, які треба врахувати: бути послідовними i «не міняти коней на переправі»; не приймати поспішних, економічно не прорахованих рішень; чітко визначати провідні напрямки розвитку кожної з зон, налагодити чіткий контроль за ходом їх розвитку; залучати до їх розвитку достатньо передових інвесторів спростити систему прийняття рішень 3 цих питань, позбавити іiі зайвої бюрократизації .

\section{Література:}

1. Попович О. С., Редько К. Ю. До питання про ефективність податкових пільг у спеціальних економічних зонах. Наука та наукознавство. Київ, 2013. № 1(179). с. 31-37.

2. Лазарєва $€$. В. Роль і функції технологічних парків у формуванні інноваційної інфраструктури країни. Економіка: реалії часу. Науковий журнал. 2014. № 3 (13). с. 197202.

3. Офіційний сайт Державної служби статистики України. URL: http://www.ukrstat.org.ua. (дата звернення: 17.10.2017). 
4. Пи Цяньшэн, Ван Кай. Опыт китайских зон технико-экономического развития. Санкт-Петербург : С.- Петер. ун-т, 2006. 487 с.

5. Маліцький Б. А. Наука, технології, інновації та національна безпека: теоретичні та прикладні аспекти. Київ : Софія, 2014. 56 с.

6. Андрощук Г. О., Жиляєв І. Б., Чижевський Б. Г., Шевченко М. М. Стратегія інноваційного розвитку України на 2010-2020 рр. в умовах глобалізаційних викликів. Київ, 2009. $632 \mathrm{c}$. 